\title{
Transformations of the herpetofauna of South- Western Kyzylkum (Uzbekistan) under the influence of technogenesis
}

\author{
Elmurad Shernazarov, and Fazliddin Jumayev ${ }^{*}$ \\ Institute of Zoology, Academy of Science of the Republic of Uzbekistan, Tashkent, Uzbekistan
}

\begin{abstract}
The diversity of herpetofauna in the natural ecosystem of the southwestern part of Kyzylkum has been studied quite deeply. In recent decades, vast desert areas have been developed for agricultural crops, and a network of irrigation facilities has been set up for watering and water supply development of new lands and socio-cultural objects. However, the study of the animal world, including the complex of amphibians and reptiles under the influence of anthropogenic factors, has been overlooked in the transformed areas. In this paper, we present the impact and consequences of man-made factors on herpetofauna of the developed areas of the Bukhara region, using the example of hydraulic structures collectors. The studies were carried out along the Northern collector at the Ramitan and Shafirkan stationary points. Seasonal field works were carried out from March to May and in September 2018, in October-November 2019 , and June-August 2020. The population density of the species was determined based on permanent and selective routes. In total, about 80 day-time and nighttime observations were carried out, with a length of more than $130 \mathrm{~km}$. The fauna of the studied area is represented by two species of amphibians and 17 species of reptiles, including three species which are listed in the Red Book of Uzbekistan and Annex I and II of CITES of which one is the IUCN Red List. According to the seasons of the year, the current state of the species population, their habitats, the dynamics of population, and the ratio of adults to young individuals are described. The expansion of the territorial space of two species of amphibians and two species of reptiles in connection with the construction of the collector-drainage network system was established. Detailed data on the negative impact of irrigation agriculture on desert species that are on the verge of complete extinction in the developed areas are provided. It is advisable to conduct conservation activities on critically endangered species regularly.
\end{abstract}

\section{Introduction}

The biosphere has been destroyed in many regions of our planet, and a new type of habitat the technosphere - has been created as a result of technogenesis [1]. The present work is

*Corresponding author: fazliddin_jumayev90@mail.ru 
devoted to the study of transformation and formation of herpetofauna under the influence of technogenesis of southwestern Kyzylkum.

To develop the steppe zones and, accordingly, increase the water supply of the irrigated lands of Bukhara oasis (South-western Kyzylkum), the Amu-Karakul, and Amu-Bukhara canals, originating from the right bank of the Amudarya river, were built. To improve the water supply of Bukhara city and several districts of the Bukhara region, 65 hydrotechnical structures, including 11 pump stations, were built on the Amu-Bukhara canal. Outlet branches are the North-West, Shafirkan, and Kharkur. The rate of development of new lands for agricultural plants has been significantly increased by implementing irrigation and land reclamation works. Cotton, cereals, melons, vegetable crops, orchards, and vineyards occupy large areas of irrigated land. To prevent soil salinization in agricultural land, the irrigated land requires the drainage of groundwater. In this regard, in the last 50 years, the length of the collector-drainage network has increased significantly, mainly due to the construction of several collectors that discharge into the Northern collector. It is the longest $(153.9 \mathrm{~km})$ collector with a width of $10-15 \mathrm{~m}$, in some areas $20 \mathrm{~m}$ or more. This waterway passes through the developed and desert parts of the Bukhara region and discharges the water into the depression of Lake Karakir [2]. Absolutely unusual environmental conditions for some species of water level fluctuation reptiles have developed along the collector channel, i.e., reed thickets of different densities, salt flats, and filtering shallow lakes with water-level fluctuation. It is home to white saxaul, tamarix, camel's thorn, bean caper, climacoptera, and ephemeral vegetation.

The influence of irrigation agriculture on some species and general on the complex of amphibians and reptiles attracts specialists from the near and far abroad. The study of the positive and negative impact of water supply development on the fauna is disclosed to varying degrees [3-10].

Academic information on the herpetofauna of the developed zones of Uzbekistan is rather limited, fragmentary, and outdated [11-15]. Information on the distribution and ecology of amphibians and reptiles in the natural territories of the Kyzylkum desert is shown in a more significant work of Zakhidov T.Z. [16].

To determine the impact and consequences of the construction of hydraulic structures on species composition and population of amphibians and reptiles, we conducted the work in the part of the Northern collector located in the agrobiocenosis of the Bukhara oasis.

\section{Methods}

The research carried out in the developed territories to study the current state of herpetofauna in the conditions of anthropogenic impact on the example of the construction of hydraulic structures served as a material for this article. On the Northern collector channels, the most characteristic, stationary points - Ramitan and Shafirkan - were selected (Figure 1). 


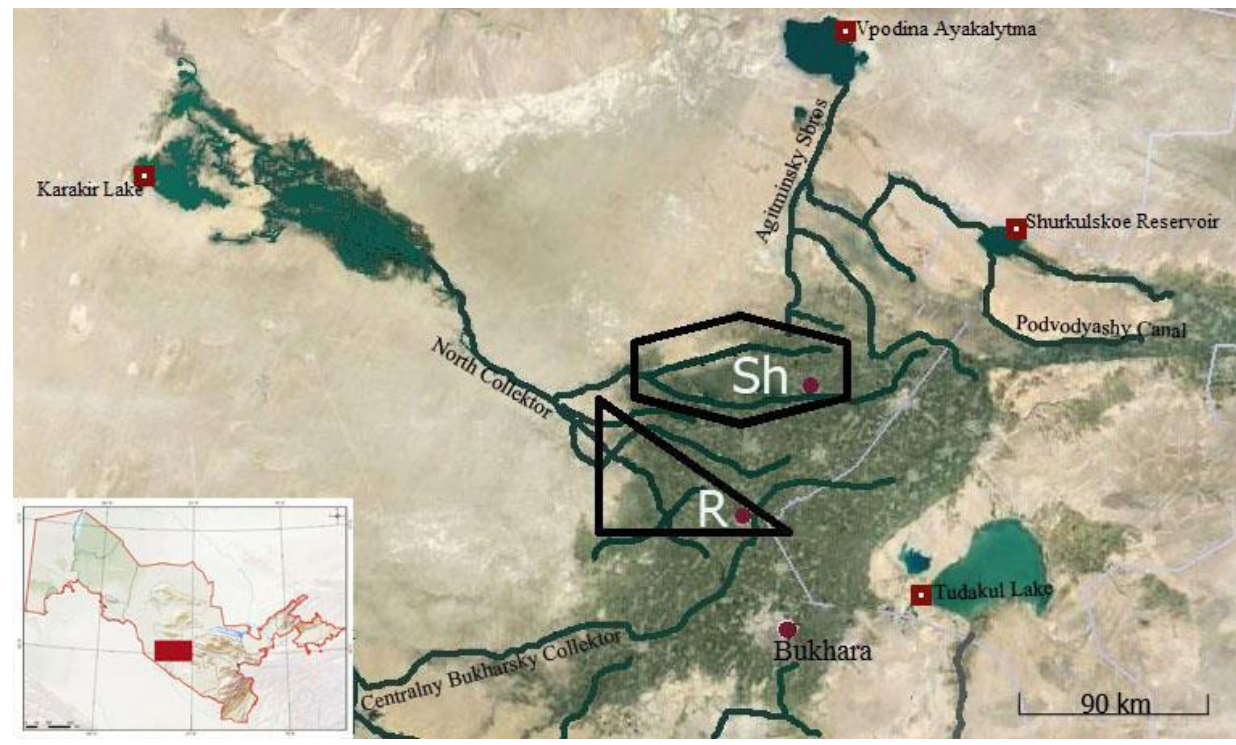

Fig.1. Herpetological research stations. $S h$ - Shafirkan, $R$ - Ramitan

The spring fieldwork was conducted from March 16 to May 23, 2018, and during the summer season, the research was conducted from June 27 to August 21, 2020. The autumn collection of material was carried out in early September 2018 and from October 10 to November 13, 2019.

The population of herpetofauna was determined by records on permanent and selective transects $[17,18]$ along the shoreline of the collector. In the spring period, 32 day-time records were conducted. The total length of the route records was $69.6 \mathrm{~km}$ with a width of 2 $\mathrm{m}$. In the summer months, 25 records were conducted ( 22 day-time, 3 nighttimes). The length of route records is $34.5 \mathrm{~km}$, including $29.5 \mathrm{~km}$ in daylight time and $5.0 \mathrm{~km}$ in the nighttime. In the autumn season, 22 records were conducted ( 20 day-time, 2 nighttimes). The length of route records is $27.0 \mathrm{~km}$, of which the daylight time is $23.0 \mathrm{~km}$, the nighttime is $4.2 \mathrm{~km}$. The obtained data on reptiles are extrapolated to 1 ha, amphibians to $1 \mathrm{~km}$.

The names of the species are given following the taxonomy adopted in "The reptiles of the Western Palearctic" [19, 20].

\section{Results and Discussion}

The studied territories were developed until the 50s of the last century for agricultural crops - much earlier than the construction of the Northern collector. After additional water supply development, the developed areas (agricultural areas, settlements, roads) have been expanded considerably. The herpetofauna complex underwent major changes in the transformed areas, in particular along with the hydraulic structures. Along the Northern collector in shallow waters, on the semi-stabilized sands of the coast, on weed-saltwort vegetation areas, 2 species of amphibians of 2 families of 1 order, and 17 species of reptiles belonging to 9 families, and 3 orders were registered (Table 1).

Green toad Bufotes viridis (Laurenti, 1768) was found irregularly and in small numbers during the study period. The population density was 0.7 individuals/ha in March, 0.1 - in April, and 0.2 - in May.

Marsh frog Pelophylax ridibundus (Pallas, 1771) is the most abundant species. It was found on the coastal part of the collector on all record days during the study period. In 
March, at a distance of $1 \mathrm{~km}$, the population ranged from 4.5 to 40 individuals. In April, the population of frogs increases significantly, so in the first half of the month, we recorded from 7.5 to 414.6 individuals per $1 \mathrm{~km}$. It was also regularly recorded during May, but the population decreased by more than half compared to April and ranged from 0.5 to 211.4 individuals. In summer, there were from 24 to 260 frogs: 56-253 - in June, 25-260 - in July, and 24-256 - in August. In October, the population remained unchanged, and in November decreased significantly - only a single individual was recorded (Figure 2).

Table 1. Herpetofauna and conservation status of the Northern collector (Bukhara oasis)

\begin{tabular}{|c|c|c|}
\hline Taxon & $\begin{array}{c}\text { Locati } \\
\text { on }\end{array}$ & Conservation status \\
\hline \multicolumn{3}{|l|}{ AMPHIBIANS, AMPHIBIA } \\
\hline \multicolumn{3}{|l|}{ Order. TAILLESS AMPHIBIAN, ANURA } \\
\hline \multicolumn{3}{|l|}{ Family. Toad, Bufonidae } \\
\hline Green toad, Bufotes viridis & $\mathrm{R}, \mathrm{Sh}$ & \\
\hline \multicolumn{3}{|l|}{ Family. Frog, Ranidae } \\
\hline Marsh frog, Pelophylax ridibundus & $\mathrm{R}, \mathrm{Sh}$ & \\
\hline \multicolumn{3}{|l|}{ REPTILES, REPTILIA } \\
\hline \multicolumn{3}{|l|}{ Order. TORTOISES, TESTUDINES } \\
\hline \multicolumn{3}{|l|}{ Family. Land tortoises, Testudinidae } \\
\hline Central Asian tortoise, Testudo horsfieldii & $\mathrm{R}$ & $\mathrm{UzRDB}^{\mathrm{a}}, \mathrm{RL}_{\mathrm{c}}^{\mathrm{IUCN}}{ }^{\mathrm{b}}, \mathrm{CITES}_{\mathrm{II}}$ \\
\hline \multicolumn{3}{|l|}{ Superorder. SCALY, SQUAMATA } \\
\hline \multicolumn{3}{|l|}{ Order. Lizards, SAUIA } \\
\hline \multicolumn{3}{|l|}{ Family. Dragon lizard, Agamidae } \\
\hline Brilliant ground agama, Trapelus agilis & $\mathrm{R}$ & \\
\hline \multicolumn{3}{|l|}{ Family. Gecko, Gekkonidae } \\
\hline Comb-toed gecko, Crossobamon eversmanni & $\mathrm{R}$ & \\
\hline Common wonder gecko, Teratoscincus scincus & $\mathrm{Sh}$ & \\
\hline \multicolumn{3}{|l|}{ Family. Old-World lizards, Lacertidae } \\
\hline Reticulate racerunner, Eremias grammica & Sh & \\
\hline Aralo-Caspian racerunner, Eremias intermedia & $\mathrm{Sh}$ & \\
\hline Striped racerunner, Eremias lineolata & $\mathrm{Sh}$ & \\
\hline Rapid racerunner, Eremias velox & $\mathrm{R}, \mathrm{Sh}$ & \\
\hline \multirow{3}{*}{\multicolumn{3}{|c|}{$\begin{array}{l}\text { Family. Skink, Scincidae } \\
\text { Desert lidless skink, Ablepharus deserti } \\
\text { Family. Monitors, Varanidae }\end{array}$}} \\
\hline & & \\
\hline & & \\
\hline Gray monitor, Varanus griseus & $\mathrm{R}$ & UzRDB, CITES I \\
\hline \multicolumn{3}{|l|}{ Order. Snakes, Serpentes } \\
\hline \multicolumn{3}{|l|}{ Family. Constricting snakes, Boidae } \\
\hline Dwarf (sand) boa, Eryx miliaris & Sh & UzRDB, CITES II \\
\hline \multicolumn{3}{|l|}{ Family. Colubrid snakes, Colubridae } \\
\hline Spotted desert racer, Platyceps karelini & $\mathrm{R}, \mathrm{Sh}$ & \\
\hline Spotted whip snake, Hemorrhois ravergieri & $\mathrm{R}, \mathrm{Sh}$ & \\
\hline Dion ratsnake Elaphe dione & $\mathrm{R}, \mathrm{Sh}$ & \\
\hline Dice snake, Natrix tessellata & $\mathrm{R}, \mathrm{Sh}$ & \\
\hline Diadem snake, Spalerosophis diadema & $\mathrm{Sh}$ & \\
\hline \multicolumn{3}{|l|}{ Family. Lamprophiidae } \\
\hline Steppe ribbon racer, Psammophis lineolatus & $\mathrm{R}, \mathrm{Sh}$ & \\
\hline
\end{tabular}


${ }^{c}$ CITES - Appendix of the Convention on the International Trade in Endangered Species of Wild Fauna and Flora [23].

Central Asian tortoise Testudo horsfieldii (Gray, 1844) has survived in the developed areas for the past 70 years, although its population is low. In March-May, only a few individuals were recorded, with the less frequent occurrence, and population density was 0.1 individuals/ha. In April, they were found relatively more frequently with a density of 0.6 .

Steppe agama Trapelus agilis (Olivier, 1807) on this patch of agricultural landscape is rare. The population density in spring is 0.1 individuals/ha. The number increases during the summer period (0.4-0.6). Since the second half of July, young agamas have been recorded. The ratio of adults and young individuals was 1.0:1.0 in July, 1.0:2.0 in August, and 2.0:1.0 in October. It is found along with the collector in rare limited areas.

Comb-toed gecko Crossobamon eversmanni (Wiegmann, 1834) is a rare species. The population density during the summer-autumn period is 0.2 individuals/ha. The ratio of adults and young geckos is 1.0:1.0. Just like the steppe agama, it was recorded in small local areas along with the collector.

Skink gecko Teratoscincus scincus (Schlegel, 1858) is a very rare species. It was preserved in the more recently developed areas of the Bukhara oasis. It is found in limited sites of the study area. On October 24, two adults and one young gecko were counted.

Reticulate racerunner Eremias grammica (Lichtenstein, 1823) was recorded with 1.7 individuals/ha in October and 3.0 in November. The ratio of adults to young individuals is 1.0:1.1 and 1.0:1.5, respectively. Just like with previous species, they were observed on the transect at certain small areas along the water channel.

Middle racerunner Eremias intermedia (Strauch, 1876) is a small species. The population density was 0.7 individuals/ha in March, 0.3 in April, 0.1 in May, 0.2 in June, 0.3 in July, 0.2 in August, and 0.1 in October. The habitat area of the species is steadily declining.

Striped racerunner Eremias lineolata (Nikolsky, 1896), like previous species of geckos and lizards, belongs to the small group. The population density was 0.2 individuals/ha in March, 0.8 in April, 0.4 in May, and 0.7 in June. Since July, there has been a slight increase in the number due to the appearance of young individuals - in July 1.0 individuals/ha (the ratio of adults to young individuals - 1.5:1.0), in August - 1.2 (1.4:1.0), and in October - 0.9 (2.0:1.0).

Fast lizard Eremias velox (Pallas, 1771) is a usual species for the studied area, occurs regularly. In March, from 0.2 to 10 individuals/ha were recorded. In April, the population doubled (min.- 0.5 individuals, max. - 13.3). The number decreased in May, although between 0.7 and 16.6 were counted on the routes. In the first half of July, the young individuals appeared. Still, the population remains the same as the previous month, and starting from August has gradually increased (between 1.0 and 24.0 individuals were recorded in October). The number of Rapid racerunner fluctuated throughout the entire period of activity (Figure 3). The ratio of adults to young individuals in July is 2.5:1.0, in August-1.0:1.2, in September-1.0:1.2, and in October-1.6:1.0. 


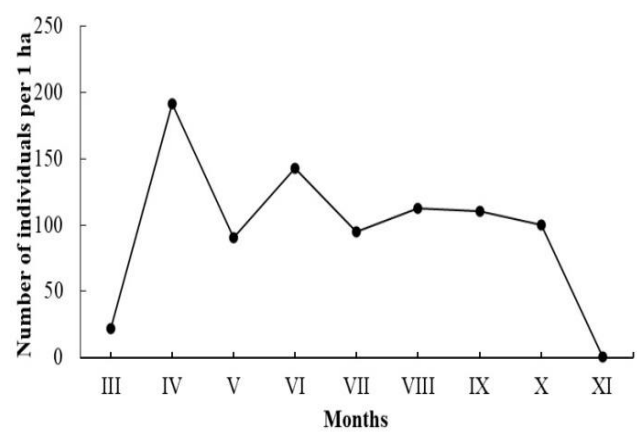

Fig. 2. Population of the Pelophylax ridibundus

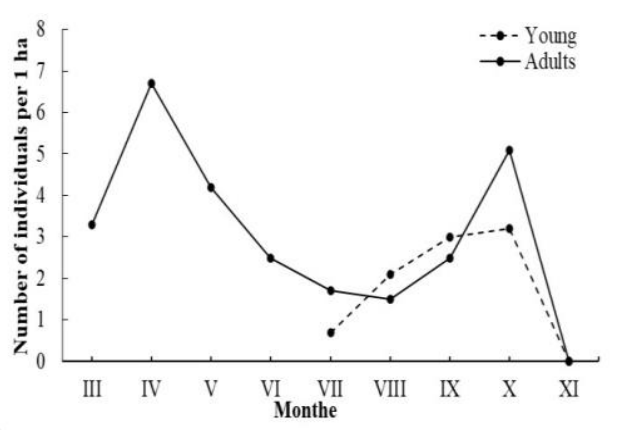

Fig. 3. Population of the Eremias velox

Desert golgaz Ablepharus deserti (Strauch, 1876) is typical species for the high humid area. It is regularly found near the collector and is a second highly populated species after the lake frog $P$. ridibundus. In all seasons of the year, the number fluctuates widely, in March from 0.8 to 17 individuals/ha, in April it almost doubles, at that time it was between 0.5 and 13.3. In May, the species' population declined, with between 1.0 and 9.2 individuals/ha recorded. There was an increase in the number of young individuals during the summer period (Figure 4), and they have been recorded since the first decade of July. The ratio of adults to young individuals in July was 1.5:1.0, in August -2.1:1.0, in September-1.3:1.0, and in October-1.0:1.1.

Gray monitor lizard Varanus griseus (Daudin, 1803) is a very rare species. On July 22,2019 , it was recorded not far from the collector. It lives in a strip formed during the construction of a hydraulic structure, as it finds shelter in the burrows of rodents.

Steppe (sandy) boa Eryx miliaris (Pallas, 1773) is one of the very rare species in the collector area of developed territories ( 0.1 individuals/ha).

Spotted desert racer Platyceps karelini (Brandt, 1838) is not common; the population density is 0.1 individuals/ha.

Spotted whip snake Hemorrhois ravergieri (Menetries, 1832) is a rare species. During the entire spring period, the population density was 0.1 individuals/ha, and in summerautumn seasons - 0.2-0.3. Young snakes were recorded on August 17, and the occurrence increased slightly by autumn.

Dione ratsnake Elaphe dione (Pallas, 1773) in terms of occurrence and population is similar to the Spotted whip snake Hemorrhois ravergieri. The young snake was recorded on August 14, and the occurrence increased in October.

Dice snake Natrix tessellata (Laurenti, 1768) is a typical inhabitant of the Northern collector. It was not observed in March. The first snake was counted on April 10. In May, between 0.3 and 1.8 individuals/ha were seen regularly. During the summer and autumn months, the numbers increase, and October is the second peak (the first peak is formed in May and June) (Figure 5). In the second half of August, young snakes were recorded. The ratio of adults to young snakes in August -1.8:1.0, in September-1.0:1.0, in October-1.0:1.1, and in November-1.0:1.0. 


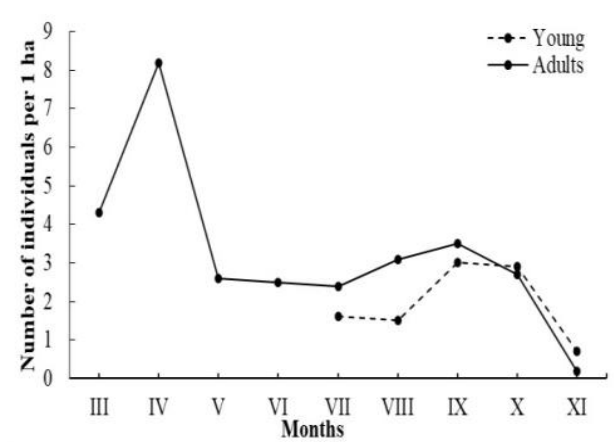

Fig. 4. Population of the Ablepharus deserti

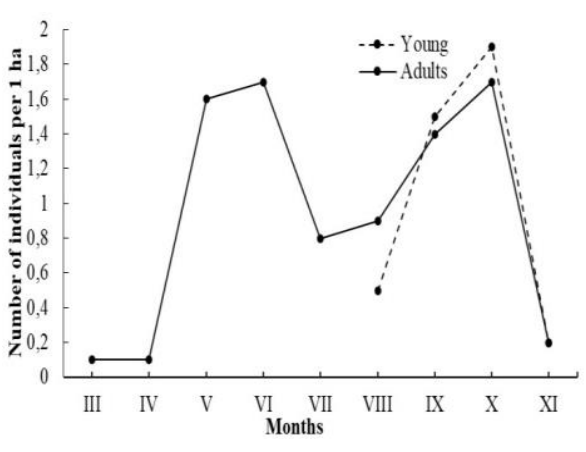

Fig. 5. Population of the Natrix tessellata

Steppe ribbon racer Psammophis lineolatus (Brandt, 1838) was observed in October and November; the population density is 0.3 individuals/ha, in November -0.2 .

Diadem snake Spalerosophis diadema (Schlegel, 1837) is a rare species group. It is observed where other psammophilus species are found. In October and November, the population density was 0.2 individuals/ha.

The study results show that small natural areas remain despite the high pressure of the anthropogenic pressure in arid areas of southwestern Kyzylkum, in the form of destruction of reptile habitats in the newly developed areas. In these local areas, the species composition and population are preserved unequally in terms of the occurrence of species inherent in sandy deserts and their population density. This is probably due to the long-term existence of the necessary conditions for the sustenance of species on small elevations unsuitable for farming. Using modern agricultural technology, the unused land area is annually included in the turnover and turned into fertile soil for cultivated plants. In this situation, the population of psammophilus species - Steppe agama Trapelus agilis, Combtoed gecko Crossobamon eversmanni, Skink gecko Teratoscincus scincus, Reticulate racerunner Eremias grammica, Middle racerunner Eremias intermedia, Ruled racerunner Eremias lineolata, Steppe (sandy) boa Eryx miliaris, Diadem snake Spalerosophis diadema - suffer first from negative factors. As a result of the direct negative impact of hydraulic structures, the reptile population eventually became small or rare, and some are on the verge of extinction.

In the Bukhara oasis, the construction of the hydraulic structures simultaneously positively affected the population size of some amphibian and reptile species. Thus, the collector and shallow lakes formed as a result of filtration in some places along the runoff play an important role in expanding the habitat and successful reproduction of Marsh frog, which contributes to the growth of its population. The same can be said about the Dice snake. Currently, it is observed along the entire length of the Northern collector, in discharge channels, and on the shoreline of Lake Karakir. At the same time, the intensive expansion of the humid areas of the arid zones gave a great impetus to the development of a new area for the Desert lidless skink.

Among the reptiles, the Rapid racerunner leads a more stable lifestyle.

Usually, during the construction of the collector, a narrow strip of elevation is formed along with it, which is further used as transport roads. Here one can observe the Green toad, Central Asian tortoise, Rapid racerunner, Desert lidless skink, Spotted desert racer, Spotted whip snake, Dione rat snake, Dice snake, and Steppe ribbon racer. While crossing the road, they die under the wheels of vehicles during the search for food, shelter, and other active phases.

Irrigation systems isolate most reptile species geographically, and this also applies to protected species. In the studied areas, three species included in the Red Book of 
Uzbekistan were registered (Table 1). At the moment, there is no chance for their preservation in the developed territories.

\section{Conclusions}

It should be noted that the species composition of herpetofauna in the developed areas along the Northern collector is rich.

Two species of amphibians and 17 species of reptiles were recorded in the studied areas of the Northern collector. Almost all herpetofauna species that live in the agricultural landscapes of the Bukhara oasis are represented, except for two species: the Caspian benttoed gecko Tenuidactylus caspius and the Grey thin-toed gecko Mediodactylus russowi.

The Northern collector played a major role in expanding the habitat of only three species - Marsh frog P. ridibundus, Dice snake Natrix tessellata, and the Desert golgaz A. deserti in the lower reaches of the river Zarafshan.

One species is numerous - Marsh frog P. ridibundus, and four species are common: Green toad B. viridis, Fast lizard E. velox, Desert golgaz A. deserti, Dice snake $N$. tessellate, and six species are insignificant: Central Asian tortoise A. horsfieldii, Steppe agama T. agilis, Middle racerunner E. intermedia, Ruled racerunner E. lineolata, Spotted whip snake $H$. ravergieri, Dione rat snake $E$. dione.

Due to degradation of natural biotopes in the developed areas, the psammophilus species (Steppe agama T. agilis, Comb-toed gecko C. eversmanni, Skink gecko T. scincus, Reticulate racerunner E. grammica, Middle racerunner $E$. intermedia, Ruled racerunner $E$. lineolata, Steppe (sandy) boa E. miliaris, Diadem snake $S$. diadema) are in a critical state of complete extinction.

It is necessary to increase awareness campaigns to protect rare and endangered species and, in general, components of biodiversity among the employees of management organizations, water resource operators, and the local population.

\section{References}

1. Krapivin V F and Kondratev K Y, Global environmental changes: ecoinformatics (Saint-Petersburg: Saint-Petersburg Scientific Center) p. 724. (2002)

2. Kulmatov R A, Rasulov A B and Nigmatov A N. The problems of sustainable use and management of irrigated lands of the Bukhara region, Uzbekistan J Problems of desert development (Ashkhabad) 1-2 pp 18-25. (2017)

3. Duysebaeva T N, Berezovikov N N, Brushko Z K, Kubykin R A and Khromov V A, Marsh frog (Rana ridibunda Pallas, 1771) in Kazakhstan: range changing and recent distribution J Modern herpetology 3 (4). pp 29 -59. (2005)

4. Berezovikov N N, Duisebayeva T N, Khromov V A and Starikov S V, New data on the distribution of Rana ridibunda at the southeast of Kazakhstan (Pushchino Moscow: Proceedings of the 1TH meeting of the Nikolsky herpetological society) pp 26-28. (2001)

5. Dotsenko I B and Radchenko V I, herpetofauna of anthropogenic landscapes of Nikolaev and Odessa regions J Collection of works Zoological Museum. 37. pp. 109120, (2005)

6. Said-Aliev S A, Amphibians and reptiles of the Yavan valley of Tajikistan. (Leningrad February 1-3: Herpetology issues. The Fourth All-Union Herpetological Conference. Abstract of reports Pudlishing house "Nauka" Leningrad branch) p. 187. (1977) 
7. Khandogiy A V, The impact of drainage reclamation on batrachofauna of Belarus (Kiev October 10-12: Materials of the 1st Conference of the Ukrainian Herpetological Society pp. 172-175 (2005).

8. Misyura A N, Marchenovskaia A A and Chernyshenko S V, The use of indicators of amphibian biodiversity in the system of biomonitoring the state of zoocenosis in the conditions of anthropo-technogenic influence. (Ioshkar Ola Pushkino January 27 February 1: Principles and Methods of Biodiversity Conservation Proceedings of the III All-Russian Scientific Conference) pp, 75-76. (2008)

9. Kotenko T I, impact of irrigation on herpetocomplexes in the Crimean Prisivashye. Biodiversity and the role of zoocenosis in natural and anthropogenic ecosystems (Dnepropetrovsk: Materials of the Third International Scientific Conference) pp. 392394. (2005)

10. Martin T, Guillemin M, Nivet-Mazerolles V, Landsmann C, Dubos J, Eudeline R and Stroud J, The herpetofauna of central Uzbekistan (Amphibian \& Reptile Conservation 11 (1) General Section) pp. 93-107. (2017)

11. Bogdanov O P. Changes of herpetofauna under the influence of irrigation J Reports of Academy of Sciences of the USSR (Moscow), 108, (6) pp. 1177 - 1178 (1956).

12. Bogdanov O P, Changes of herpetofauna during irrigation of virgin and fallow lands of Uzbekistan (Almaty: Materials for the conference on zoogeography of land., Publishing House Academy of Sciences of the Kazakh SSR) pp. 26-27. (1960)

13. Bogdanov O P, Ecology of reptiles of Central Asia. Tashkent: Science, p. 257 (1965)

14. Pavlnko T A, Vertebrates of the Golodnaya Steppe. (Tashkent: The animal world of the Golodnaya Steppe) pp. 127-175. (1962)

15. Vashetko $\mathrm{E} \mathrm{V}$, The abundance and biomass of some species of reptiles in natural and anthropourgic conditions of Jizzakh region (Leningrad: Herpetology issues: abstracts of reports of the 5th All-Union Herpetological Conference) p. 29 (1981)

16. Zakhidov T Z, Biocenoses of the Kyzylkum desert (Tashkent: Publishing house "Fan") p. 303. (1971)

17. Dinesman L G and Koletskaya M P, Methods of quantitative accounting of amphibians and reptiles (Moscow, SSSR: Methods of accounting for the number and geographical distribution of terrestrial vertebrates Academy of Sciences Publishing House) pp. 329-341. (1952)

18. Sherbak N N Amphibians and reptiles of the Crimea (Kiev: Scientific thought) p. 240. (1966)

19. Sindaco R and Jeremcenko V K, The reptiles of the Western Palearctic (Latina, Italy: Annotated Checklist and Distributional Atlas of the Turtles, Crocodiles, Amphisbaenians and Lizards of Europe, North Africa, Middle East and Central Asia. Edizioni Belvedere) 1. p 579. (2008)

20. Sindaco R, Venchi A and Grieco C, The Reptiles of the Western Palearctic (Latina, Italy: Annotated checklist and distributional atlas of the snakes of Europe, North Africa, Middle East and Central Asia. Edizioni Belvedere) 2. p. 544. (2013)

21. Red book of the Republic of Uzbekistan. Reptiles Vol II «Chinor ENK» Tashkent pp. 113-127 (2019)

22. The IUCN Red List of Threatened Species. 1. Available: www.iucnredlist (Accessed: July 02 2016).

23. Checklist of CITES Species. (2020). http://checklist. cites.org. 